\title{
Assessment of Çinarli Stream (Hafik -Sivas)'S Water Quality via Physico-Chemical Methods
}

\author{
Ekrem Mutlu $^{1^{*}}$, Banu Kutlu², Tuğba Demir ${ }^{3}$ \\ ${ }^{1}$ Department of Aquaculture, Faculty of Fisheries, Kastamonu University, 37150 Kastamonu, Turkey \\ ${ }^{2}$ Department of Basic Sciences, Faculty of Fisheries, Tunceli University, 62000 Tunceli, Turkey \\ ${ }^{3}$ Department of Nourishment, Hafik Kamer Ornek Vocational School, Cumhuriyet University,58760 Hafik/Sivas, Turkey
}

\section{A R T I C LE INFO}

\section{Article history:}

Received 15 July 2015

Accepted 21 September 2015

Available online, ISSN: $2148-127 \mathrm{X}$

Keywords:

Water pollution

Sivas

Hafik

Çınarlı stream

Water quality criteria

${ }^{*}$ Corresponding Author:

E-mail: ekrem-mutlu@ hotmail.com

\begin{abstract}
A B S T R A C T
Çınarlı Stream within the borders of Hafik district of Sivas city is famous for its natural beauties and rich water resource. By passing through a steep valley, Çınarlı stream reaches at forages exhibiting gypsum characteristic of Çınarlı Village. It supplies the irrigation water needs of Koşutdere and near villages where it merges with Koç Stream, and then mixes into Kizılırmak within the borders of Hafik district. Çınarlı Stream satisfies table and usage water requirements of Çınarlı, Bahçecik and Koşutdere villages, besides supplying the irrigation water for fertile agricultural lands near them. In this study, by observing the water quality of Çınarlı Stream via physico-chemical methods by taking samples from 6 stations on stream and analyzing these samples between October 2011 and September 2013, it has been aimed to determine and record the monthly and seasonal changes in water quality, to determine the quality criteria in accordance with Water Pollution and Control Regulation (WPCR), and to create a data base for further studies in Çınarlı Stream, where no other study has been carried out.
\end{abstract}

Türk Tarım - Gıda Bilim ve Teknoloji Dergisi, 4(4): 267-278, 2016

\section{Çınarlı Deresi’nin (Hafik-Sivas) Su Kalitesinin Fiziko-Kimyasal Metotlarla Değerlendirilmesi}

M A K A L E B İ L G İ S İ

Geliş 15 Temmuz 2015

Kabul 21 Eylül 2015

Çevrimiçi baskı, ISSN: 2148-127X

\section{Anahtar Kelimeler:}

Su kalitesi

Sivas

Hafik

Çınarlı deresi

Su kalitesi kriterleri

" ${ }^{\text {S Sorumlu Yazar: }}$

\section{Ö Z E T}

Sivas ilinin Hafik ilçesi sınırları dâhilindeki Çınarlı Deresi doğal güzellikleri ve zengin su kaynağı ile ünlüdür. Dik yamaçlardan geçen Çınarlı deresi Çınarlı Köyü’nün jips özelliği gösteren meralarına ulaşır. Koşutdere'nin ve Koç deresi ile birleştiği yakındaki köylerin sulama suyu ihtiyacını karşılar ve Hafik ilçesi sınırları içerisinde Kızılırmak ile birleşir. Çınarlı Deresi verimli tarımsal alanların sulama suyu ihtiyacını karşılamanın yanı sıra Çınarlı, Bahçecik ve Koşutdere köylerinin içme ve kullanım suyu ihtiyaçlarını da karşılar. Bu çalışmada; Çınarlı, Bahçecik ve Koşutdere köylerinin içme ve kullanma su ihtiyacını karşılamasının yanı sıra geçtiği bölgedeki verimli tarım arazilerinin sulama ihtiyacını da karşılayan Çınarlı deresinin Ekim 2011- Eylül 2013 tarihleri arasında belirlenen altı istasyondan aylık olarak alınan su örneklerinin analizi ile su kalitesinin fiziko-kimyasal yöntemlerle iki yıl süresince izlenerek su kalitesindeki aylık ve mevsimsel değişikliklerin belirlenerek kaydedilmesi, Su Kirliliği ve Kontrol Yönetmeliği (SKKY) göre kalite kriterlerinin belirlenmesi ve daha önce hiçbir araştırmanın yapılmadığ bundan sonra yapılacak olan çalışmalarda kullanılmak üzere bir veri tabanı oluşturulması hedeflenmiştir. 


\section{Introduction}

The protection and appropriate usage of water resources vary depending on sensitiveness of societies about this matter besides their awareness. Nowadays, the factors such as industrialization, increasing population and urbanization, global climate changes, wrong irrigation methods, unconscious usage, and excessive agricultural activities increase the pressure on protection of water resources. Becoming more threatening in both world and Turkey, the water constraint arises due to deficiency in amount and quality of water (Geyikçi and Büyükgüngör, 2010). Due to constraint of water resources and increasing pollution levels, the quality of surface waters being used for various reasons such as drinking, usage, aquaculture and agricultural irrigation should be continuously monitored (Mutlu et al., 2013a).

Water quality studies are conducted in world and our country in order to control surface waters regularly, to know physical and chemical characteristics, to use those waters in productive and planned way under the light of obtained information, and to decrease the pollution risk. Unless those negativities are followed regularly and the required measures are taken, an irreversible progress through depletion of aquatic ecosystem will occur in time (Boyacıoglu and Boyacıoglu, 2003). The rivers and streams are the ecosystems being affected from environmental pollution at first. The polluters originating from house, industrial and agricultural activities interfuse to rivers and streams at first (Bektaş et al., 2011). The arrival of agricultural and domestic wastes around the rivers and streams to recipient environment via various ways leads that environment to be polluted. Especially the homogenous medias such as water become polluted easily, and they can clean themselves if the resource of pollution is removed (Okur et al., 2001).

The obvious change in agricultural and industrial activities in last 30 years is one of the human-originated factors of degradation of soil and water resources in Sivas city (Mutlu et al., 2013a).

The Çinarlı stream, where the study was conducted, merges to Koru stream and passes through agricultural fields and residential areas thru the point where Kizılirmak flows into sea, and it is the recipient of drainage waters of nearby agricultural fields in most places. Not only for Sivas city, the Hafik district of Sivas city is cereal center of also central Anatolia region, and is also a mischance for Çınarlı stream.

Çınarlı stream is in an important position for Çınarlı village and nearby villages. As well as it supplies the table water and the daily water needs of Çınarlı, Bahçecik and Koşutdere villages, it also supplies the irrigation water needs of large and productive areas.

The objective of this study is to observe the water quality of Çinarlı stream for 2 years between October 2011 and October 2013 via physiochemical methods through water samples obtained monthly from 6 determined stations, to record the water quality values monthly and seasonally and determine the changes, to determine the quality criteria according to classes of intracontinental water resources according to Water Quality Control regulation (WPCR), and to create a database to be used in future studies for water quality of Çınarlı stream where there has never been any research.

\section{Material and Method}

Located within the borders of Hafik district of Sivas city in upper Kızılırmak basin of central Anatolia, Çınarlı stream is famous for its natural beauties and being a rich water resource (Figure 1). Being far away $53 \mathrm{~km}$ from Sivas city and $20 \mathrm{~km}$ from Hafik district, Çınarlı village has a very high water potential, and has an important place with its village residential area and stock farming center in Sivas city. The resource of Çınarlı stream is Kösedağ. Passing through a steep valley, the Çınarlı stream reaches to Çınarlı village's meadows with gypsum characteristics. Passing through fertile lands from Çınarlı village to Koşutdere village where it merges with Koç stream, it merges with Kizilirmak within the borders of Hafik district center.

Supplying the drinking and utility water needs of Çınarlı, Bahçecik and Koşutdere villages, Çınarlı stream is very important as it constitutes the irrigation resource of fertile lands of the region.

The locations of the stations in this study have been determined as follows in order to represent the whole stream; $1^{\text {st }}$ station is $170 \mathrm{~m}$ forward from spring point, $2^{\text {nd }}$ station is in entrance of Çınarlı village, $3^{\text {rd }}$ station is exit of Çınarlı village, $4^{\text {th }}$ station is in exit of Bahçecik village, $5^{\text {th }}$ station is in exit of Koşutdere village, and $6^{\text {th }}$ station is at the point where Çınarlı stream merges with Koç stream.

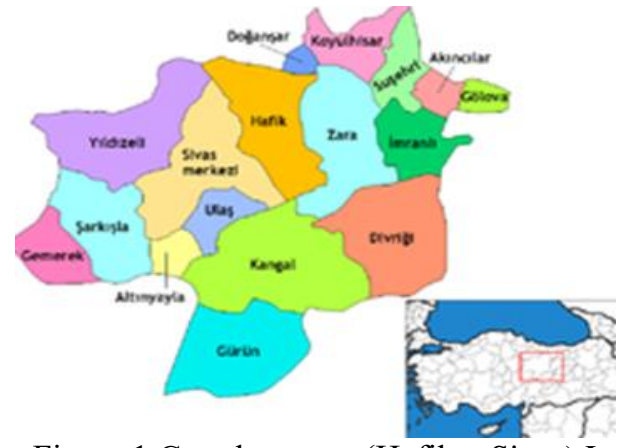

Figure 1 Çınarlı stream (Hafik - Sivas) Law

Water Analyses

The sampling has been started in October 2011 in order to determine the levels of physical and chemical parameters constituting water quality, and the analyses of samples have been conducted monthly for 2 years since September 2013.

The sample dishes used in this study have been washed acid bath $(1-2 \% \mathrm{HCl})$ and then pure water 1 day before the usage in field. Then the dished rinsed with pure water have been left in drying-oven to dry (Boyd and Tucker, 1992). By sinking the sampling dishes to almost $15 \mathrm{~cm}$ deep from water surface, the water samples have been collected through the gravity of the water. The obtained water samples have been taken to laboratory in 3 hours at most. Among the water quality parameters, the levels of dissolved oxygen (D.O.), temperature, $\mathrm{pH}$, salinity and electrical conductivity (E.C.) were measured via field-type devices. The levels of dissolved oxygen (D.O.) and temperature were measured via YSI brand 52 Model oxygenmeter, the $\mathrm{pH}$ measurement was conducted via Orion brand 420A Model $\mathrm{pH}-$ meter, and salinity (ppt) and electrical conductivity $(\mu \mathrm{s} / \mathrm{cm})$ measurements were conducted via YSI brand 30/50 FT Model conductivitymeters. 
Among other parameters determining the level of water quality; total alkalinity, total hardness nitrite $\left(\mathrm{NO}_{2}\right)$, nitrate $\left(\mathrm{NO}_{3}^{-}\right)$, ammonium nitrogen $\left(\mathrm{NH}_{4}^{+}\right)$, phosphate $\left(\mathrm{PO}_{4}^{-3}\right)$, sulfide $\left(\mathrm{SO}_{3}\right)$, sulfate $\left(\mathrm{SO}_{4}\right)$, chloride, sodium, potassium, suspended solid matter (SSM), calcium, magnesium, chemical oxygen demand (COD), biological oxygen need (BOD), ferrous, lead, copper, and cadmium levels were measured in Laboratory of Hafik Kamer Örnek Vocational High School of Cumhuriyet University in same day with samples' arrival in laboratory.

Titration method was used with sulfuric acid for total alkalinity and with EDTA for total hardness. The result values were stated in $\mathrm{mg} / \mathrm{L} \mathrm{CaCO}_{3}$ unit. By using chemical polluters, the $\mathrm{CON}$ level has been measured with method titration with ferrous ammonium sulfate based on determining the amount of oxygen usage while lysing the natural and pollutant organic load. The level of biological oxygen need (BON) has been measured via YSI 5OB oxygen-meter after keeping at $20^{\circ} \mathrm{C}$ for 5 days. The analyses of levels of nitrite, nitrate, ammonium nitrogen, phosphate, sulfide, sulfate, chloride, sodium, potassium, calcium, magnesium ferrous, lead, copper and cadmium have been conducted in laboratory with CECIL CE4003 spectrophotometer by using Merck photometric test kits. The analysis of suspended solid matter (SSM) has been conducted by filtering the water through Whitman Nr42 $0.45 \mathrm{Nm}$ membrane filters and then measuring the weight difference.

The monthly averages of each of parameters, standard deviations and graphics have been prepared by using Office Excel 2007, a part of Microsoft Office Professional Edition 2007 product.

\section{Results}

The temperature values of Çınarlı stream varied between months, seasons, and among measurement stations. The mean water temperature value during 2 years of monthly measurement is $11.63^{\circ} \mathrm{C}$. The lowest value was measured in February 2012 as $5.84^{\circ} \mathrm{C}$ in $1^{\text {st }}$ station, while the highest value has been observed in $5^{\text {th }}$ station in September 2013 as $17.96^{\circ} \mathrm{C}$. Also the seasonal mean temperature values between October 2011 and September 2013 are as follows, respectively; winter $7.3^{\circ} \mathrm{C}$, spring $9.16^{\circ} \mathrm{C}$, summer $16.10^{\circ} \mathrm{C}$, and autumn $15.43^{\circ} \mathrm{C}$ (Figure 2).

The dissolved oxygen amount in Çınarlı stream has varied monthly and seasonally during the study period. The mean value observed during 2 years in $6^{\text {th }}$ station is $11.57 \mathrm{mg} / \mathrm{L}$, the lowest value is $8.66 \mathrm{mg} / \mathrm{L}$ in September 2013 at $5^{\text {th }}$ station, while the highest value has been observed in February 2012 in $1^{\text {st }}$ station as $14.12 \mathrm{~kg} / \mathrm{L}$. As a result of a study conducted for 2 years in 4 seasons, the mean dissolved oxygen values in winter, spring, summer and autumn seasons have been observed as follows, respectively; $13.47 \mathrm{~kg} / \mathrm{L}, 13.47 \mathrm{mg} / \mathrm{L}, 13.09 \mathrm{mg} / \mathrm{L}, 9.66$ $\mathrm{mg} / \mathrm{L}$, and $10.07 \mathrm{mg} / \mathrm{L}$ (Figure 3).

The saltiness of Çınarlı stream has varied significantly among seasons. The saltiness has decreased in winter months, but it has increased in months when water temperatures have been high. The highest value has been observed in September 2013 in $5^{\text {th }}$ station as $0.18 \mathrm{ppt}$, while the lowest value has been observed in January 2012 as $0.01 \mathrm{ppt}$ and the mean value of stations for 2 years has been found to be $0.07 \mathrm{ppt}$. The seasonal mean values of $6^{\text {th }}$ station between October 2011 and September 2013 have been found to be $0.02 \mathrm{ppt}$ for winter, $0.05 \mathrm{ppt}$ for spring, $0.10 \mathrm{ppt}$ for summer and $0.11 \mathrm{ppt}$ for autumn (Figure 4).

The electrical conductivity (EC) values of Çınarlı stream have varied between months, seasons and among 6 stations. The mean electrical conductivity value of 6 stations where the study has been conducted was found to be $201.34 \mu \mathrm{s} / \mathrm{cm}$. The electrical conductivity values, in parallel with saltiness values, have decreased in winter months and increased in months where the water temperature has been high. The value in February 2012 in $1^{\text {st }}$ station was $162.36 \mu \mathrm{s} / \mathrm{cm}$ while it reached to its highest point in September 2013 in $5^{\text {th }}$ station as $246.60 \mu \mathrm{s} / \mathrm{cm}$. Also during 2 years of measurements between October 2011 and September 2013, the seasonal mean electrical conductivity values have been found to be $172.38 \mu \mathrm{s} / \mathrm{cm}$ for winter, $192.34 \mu \mathrm{s} / \mathrm{cm}$ for spring, $222.40 \mu \mathrm{s} / \mathrm{cm}$ for summer and $218.24 \mu \mathrm{s} / \mathrm{cm}$ for autumn (Figure 5). 
mg/L

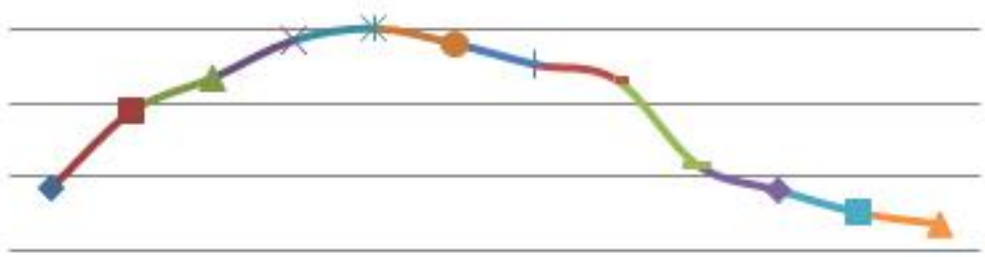

\begin{tabular}{|l|l|l|l|l|l|l|l|l|l|l|l|} 
OCT & NOV & DEC & JAN & FEB & MAR & APR & MAY & JUN & JUL & AUG & SEP \\
\hline
\end{tabular}

\begin{tabular}{l|l|l|l|l|l|l|l|l|l|l|l|l|l}
\hline -Dis. Oxygen & 9,70 & 11,78 & 12,68 & 13,70 & 14,02 & 13,61 & 13,04 & 12,63 & 10,32 & 9,64 & 9,03 & 8,72 \\
\hline
\end{tabular}

Figure 3 Mean Monthly Dissolved Oxygen Amounts of Stations (mg/L)

$0 \%$

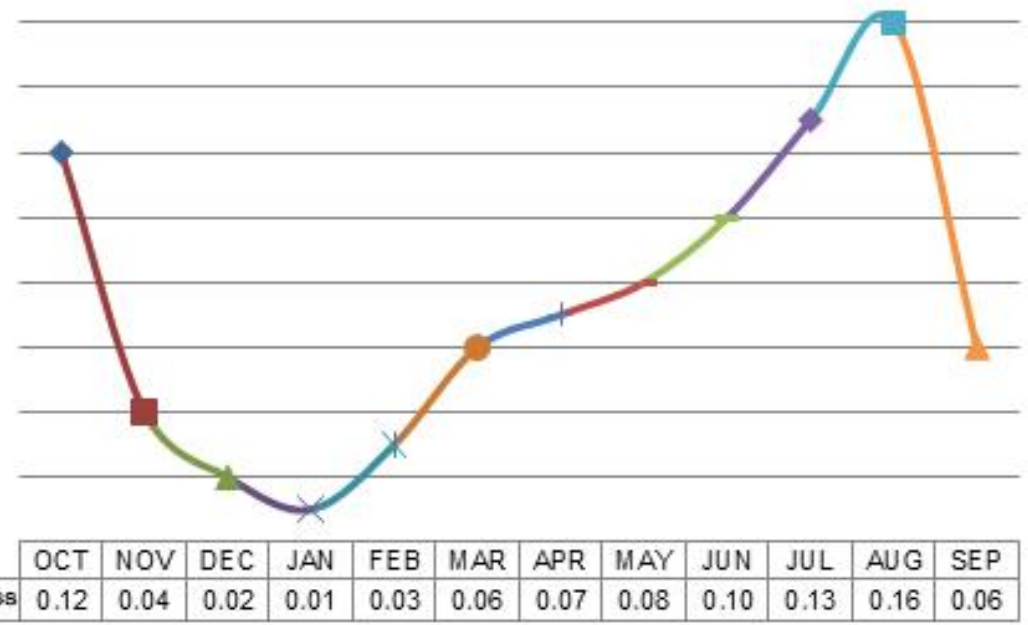

Figure 4 Mean Monthly Saltiness Values Of Stations (ppt)

$\mu \mathrm{s} / \mathrm{cm}$

\begin{tabular}{|l|l|l|l|l|l|l|l|l|l|l|l|}
\hline OCT & NOV & DEC & JAN & FEB & MAR & APR & MAY & JUN & JUL & AUG & SEP \\
\hline
\end{tabular}

C. 216.24192 .36180 .24174 .42162 .48186 .42192 .36198 .24210 .06222 .54234 .60246 .12

Figure 5 Mean Monthly Electrical Conductivity Values of Stations $(\mu \mathrm{s} / \mathrm{cm})$ 
The $\mathrm{pH}$ value showing the acidic or basic situation of waters has indicated that 6 stations on Çınarlı stream had basic characteristics. The monthly mean $\mathrm{pH}$ value of 6 work stations during 2 years of study is 8.29 . The highest $\mathrm{pH}$ value has been observed in $5^{\text {th }}$ station in September 2013 as 8.54 , while the lowest value has been observed in February 2012 in $1^{\text {st }}$ station as 8.12. The mean values in winter, spring, summer and autumn in Çınarlı stream during 2 years of study are 8.16, 8.25, 8.38 and 8.36, respectively (Figure 6).

The suspended solid matter (SSM) values of Çınarlı stream have varied between months, seasons and among 6 stations. During the 2 years of measurement, the lowest value has been observed in $1^{\text {st }}$ station in March 2012 as $0.18 \mathrm{mg} / \mathrm{L}$, while the highest value has been observed in $6^{\text {th }}$ station in September 2013 as $6.54 \mathrm{mg} / \mathrm{L}$ and the mean suspended solid matter (SSM) amount has been found to be $1.83 \mathrm{mg} / \mathrm{L}$. Also the seasonal mean suspended solid matter values during measurements between October 2011 and September 2013 have been found to be 0.66 $\mathrm{mg} / \mathrm{L}$ for winter, $0.54 \mathrm{mg} / \mathrm{L}$ for spring, $2.77 \mathrm{mg} / \mathrm{L}$ for summer and $3.38 \mathrm{mg} / \mathrm{L}$ for autumn (Figure 7).

Through the monthly evaluations, the mean chemical oxygen demand (COD) of stream during 2 years of study in 6 stations has been found to be $4.85 \mathrm{mg} / \mathrm{L}$. Minimum COD value has been observed in $1^{\text {st }}$ station in February 2012 as $0.60 \mathrm{mg} / \mathrm{L}$, while the maximum value has been observed in $5^{\text {th }}$ station in September 2013 as $9.60 \mathrm{mg} / \mathrm{L}$. The seasonal mean values of 6 stations on Çinarlı stream between October 2011 and September 2013 have been found to be $1.38 \mathrm{mg} / \mathrm{L}$ for winter, $3.37 \mathrm{mg} / \mathrm{L}$ for spring, $7.80 \mathrm{mg} / \mathrm{L}$ for summer and $6.87 \mathrm{mg} / \mathrm{L}$ for autumn (Figure 8).

During the research period, the biological oxygen demand (BOD) of Çınarlı stream has varied between months, seasons and among the study stations. The mean monthly biological oxygen need of stations where the monthly evaluations have been conducted for 2 years has been found to be $2.18 \mathrm{mg} / \mathrm{L}$. The lowest value has been observed in $1^{\text {st }}$ station in February 2012 as $0.1 \mathrm{mg} / \mathrm{L}$, while the highest value has been observed in $5^{\text {th }}$ station in September $20136.00 \mathrm{mg} / \mathrm{L}$. As a result of monthly measurements in 6 stations during October 2011September 2013, the mean seasonal biological oxygen demand (BOD) values have been found to be $0.73 \mathrm{mg} / \mathrm{L}$ for winter, $1.40 \mathrm{mg} / \mathrm{L}$ for spring, $3.33 \mathrm{mg} / \mathrm{L}$ for summer and $3.27 \mathrm{mg} / \mathrm{L}$ for autumn (Figure 9 ).

Total alkalinity and total hardness values of Çinarlı stream have showed analogy, and the results have been found to be close to each other. The total alkalinity and total hardness values of stream have showed decrease in winter months in study stations, while they have showed increase in summer months. The lowest total alkalinity value has been observed in $1^{\text {st }}$ station in February 2013 as $1.33 \mathrm{mg} / \mathrm{L} \mathrm{CaCO}_{3}$, while the highest value has been observed in $6^{\text {th }}$ station in June 2012 as $204.27 \mathrm{mg} / \mathrm{L}$ $\mathrm{CaCO}_{3}$ and the mean value during monthly evaluations for 2 years has been found to be $172.37 \mathrm{mg} / \mathrm{L} \mathrm{CaCO}_{3}$.

During the monthly measurements in stations for 2 years, the mean total hardness value of the stream has been found to be $171.44 \mathrm{mg} / \mathrm{L} \mathrm{CaCO}_{3}$. The lowest total hardness value has been observed in $1^{\text {st }}$ station in February 2013 as $134.18 \mathrm{mg} / \mathrm{L} \mathrm{CaCO}_{3}$ and the highest value has been observed in $6^{\text {th }}$ station in June 2012 as

\section{$206.36 \mathrm{mg} / \mathrm{L} \mathrm{CaCO}_{3}$}

The nitrite $\left(\mathrm{NO}_{2}\right)$, nitrate $\left(\mathrm{NO}_{3}\right)$ and ammonium nitrogen $\left(\mathrm{NH}_{4}{ }^{+}\right)$levels of Çınarlı stream have found to be lower in winter months than other seasons. No nitrite $\left(\mathrm{NO}_{2}\right)$ and ammonium nitrogen $\left(\mathrm{NH}_{4}\right)$ has been found in February 2012 in stations on stream. The highest nitrite $\left(\mathrm{NO}_{2}\right)$ level in stream has been observed in $5^{\text {th }}$ statin in July 2013 as $0.0030 \mathrm{mg} / \mathrm{L}$, and this value has been considered to be within acceptable limits.

The nitrate $\left(\mathrm{NO}_{3}\right)$ amount of Çınarlı stream is very low. While the nitrate levels have been decreases in winter months in all stations, in September 2013 when the water temperature was at highest level and the amount of dissolved oxygen was lowest, it has reached at its highest level in $5^{\text {th }}$ station as $0.90 \mathrm{mg} / \mathrm{L}$. The mean nitrate value of stream has been found to be $0.29 \mathrm{mg} / \mathrm{L}$ as a result of monthly measurements during 2 years.

The ammonium nitrogen $\left(\mathrm{NH}_{4}^{+}\right)$level of Çinarl Stream showed analog with nitrite $\left(\mathrm{NO}_{2}\right)$ values, and its highest level has been observed in $5^{\text {th }}$ station in July 2013 as $0.060 \mathrm{mg} / \mathrm{L}$. This value equals to $1 / 5$ of acceptable upper limit. Also during the monthly measurements between October 2011 and September 2013, the mean ammonium nitrogen $\left(\mathrm{NH}_{4}{ }^{+}\right)$value of stream has been found to be $0.013 \mathrm{mg} / \mathrm{L}$.

The chloride content of Çinarlı stream have varied between months, seasons and among stations between dates of October 2011 and September 2013. During the regular monthly measurement for 2 years of study, the mean chloride $(\mathrm{Cl})$ value of stream has been found to be $11.69 \mathrm{mg} / \mathrm{L}$. The lowest chloride value has been observed in $5^{\text {th }}$ station in September 2013 as $9.84 \mathrm{mg} / \mathrm{L}$, while the highest value has been observed in $1^{\text {st }}$ station in May 2012 as $13.24 \mathrm{mg} / \mathrm{L}$.

The calcium $(\mathrm{Ca})$ and magnesium $(\mathrm{Mg})$ values of Çınarlı stream have showed analogy with each other during year, while they have showed variance between months, seasons and among statins during 2 years. In months when flow rate and speed of water increased, the levels of calcium ( $\mathrm{Ca}$ ) and magnesium $(\mathrm{Mg})$ have increased and reached at their highest points. The lowest calcium $(\mathrm{Ca})$ value has been observed in $1^{\text {st }}$ station in February 2013 as $7.86 \mathrm{mg} / \mathrm{L}$, while the highest value has been observed in $6^{\text {th }}$ station in June 2012 as $16.08 \mathrm{mg} / \mathrm{L}$ and the mean value of 2 years was $12.74 \mathrm{mg} / \mathrm{L}$.

The mean magnesium $(\mathrm{Mg})$ of the stream has been found to be $12.37 \mathrm{mg} / \mathrm{L}$ as a result of monthly measurements in 6 stations during 2 years of study between October 2011 and September 2013. The lowest magnesium value has been observed in $1^{\text {st }}$ station in February $7.74 \mathrm{mg} / \mathrm{L}$, while the highest value has been observed in $6^{\text {th }}$ station in June 2012 as $15.60 \mathrm{mg} / \mathrm{L}$.

The amount of phosphate $\left(\mathrm{PO}_{4}\right)$, which is an important mineral affecting the efficiency of aquatic life, in Çınarlı stream has varied between months, seasons and among stations during 2 years of study. The mean phosphate value between October 2011 and September 2013, as a result of regular monthly measurement during 2 year, has been found to be $0.135 \mathrm{mg} / \mathrm{L}$. The highest phosphate $\left(\mathrm{PO}_{4}\right)$ value has been observed in $5^{\text {st }}$ station in October 2011 as $0.294 \mathrm{mg} / \mathrm{L}$. also the mean seasonal values during 2 years of study have been found to be $0.099 \mathrm{mg} / \mathrm{L}$ for winter, $0.072 \mathrm{mg} / \mathrm{L}$ for spring, $0.138 \mathrm{mg} / \mathrm{L}$ for summer and $0.234 \mathrm{mg} / \mathrm{L}$ for autumn (Figure 10). 


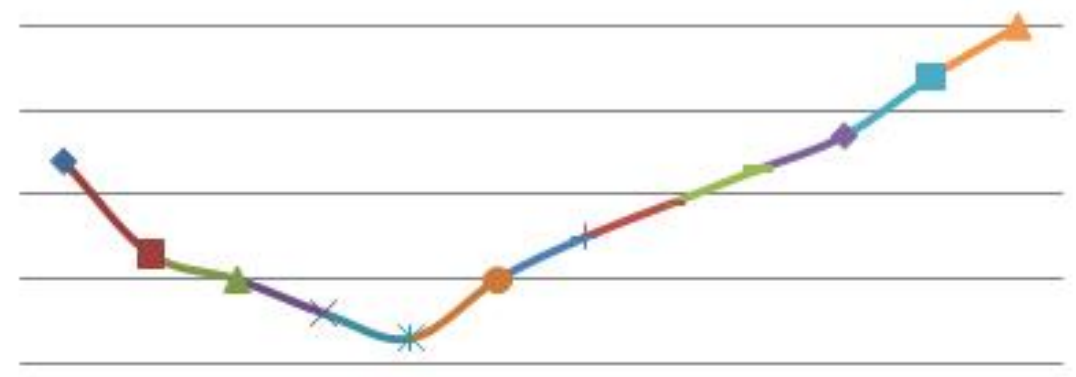

\begin{tabular}{|c|c|c|c|c|c|c|c|c|c|c|c|c|}
\cline { 2 - 11 } & OCT & NOV & DEC & JAN & FEB & MAR & APR & MAY & JUN & JUL & AUG & SEP \\
\hline $\mathrm{pH}$ & 8,34 & 8,23 & 8,20 & 8,16 & 8,13 & 8,20 & 8,25 & 8,29 & 8,33 & 8,37 & 8,44 & 8,50 \\
\hline
\end{tabular}

Figure 6 Mean Monthly pH Values of Stations

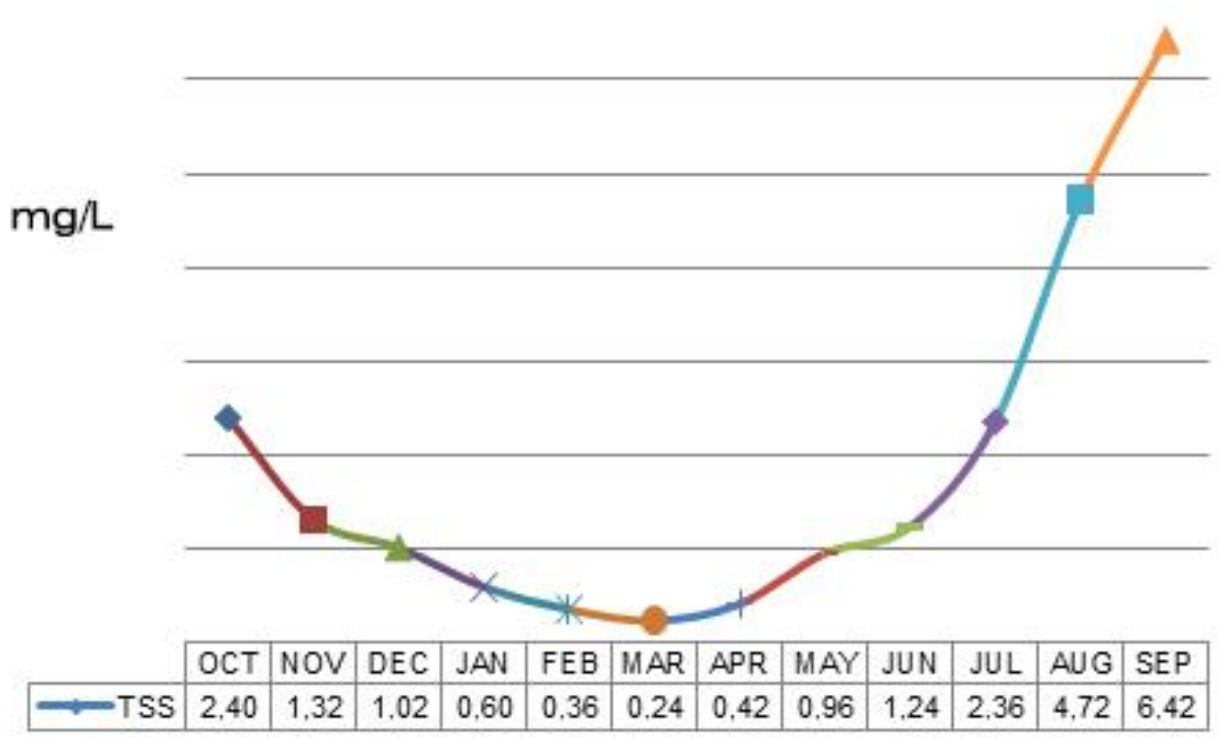

Figure 7 Mean Monthly Suspended Solid Matter Values of Stations (mg/L)

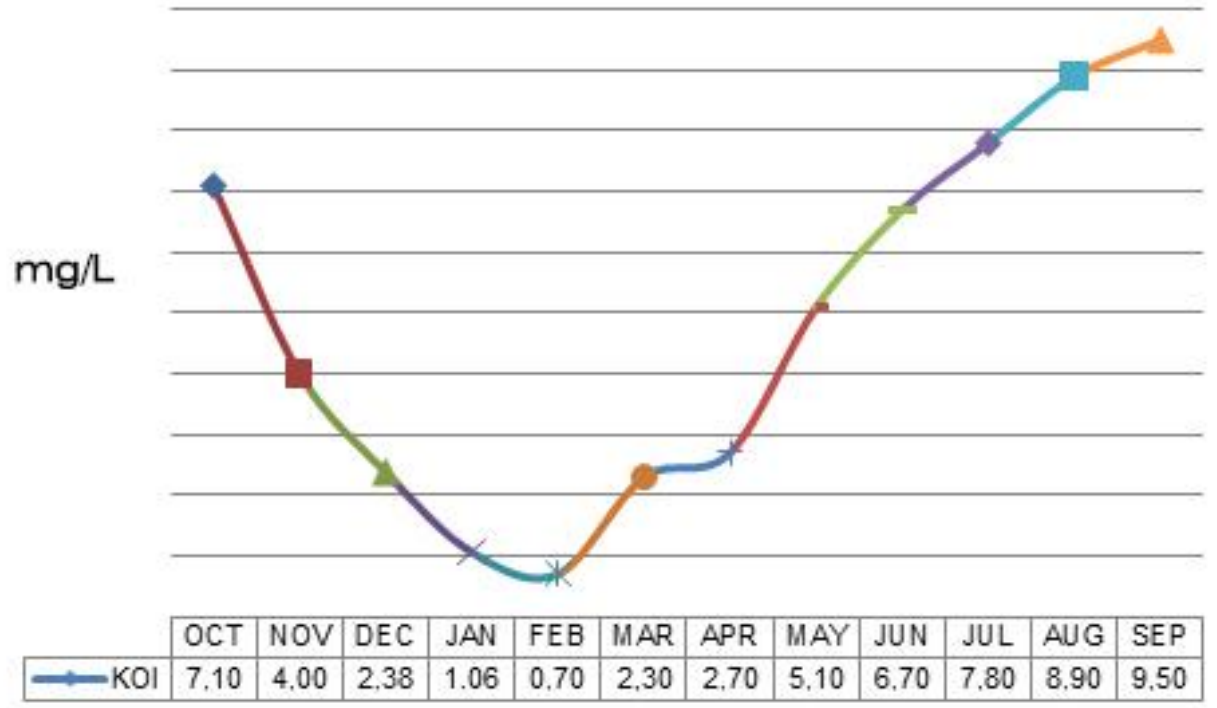

Figure 8 Mean Monthly Chemical Oxygen Demand (COD) Values of Stations (mg/L) 


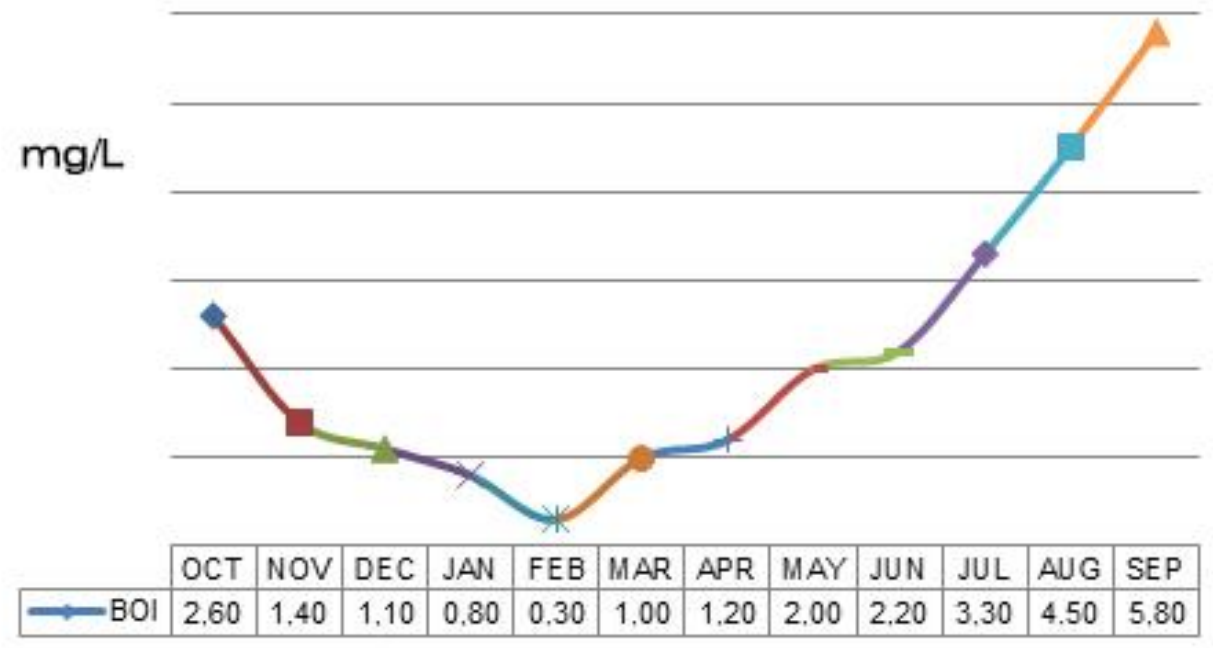

Figure 9 Mean Monthly Biological Oxygen Demand of Stations (mg/L)

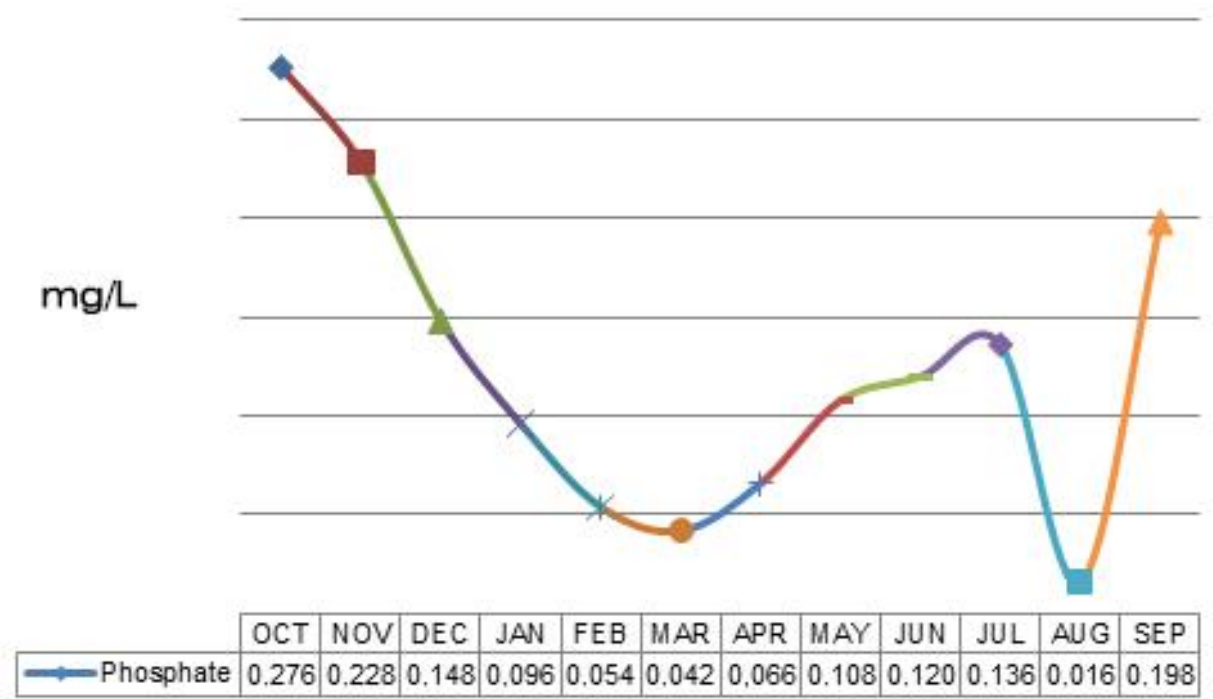

Figure 10 Mean Monthly Phosphate Values of Stations (mg/L)

The sulfite amount $\left(\mathrm{SO}_{3}\right)$ in Çınarlı Stream has been found to be very low in 6 study stations. While the amount of sulfite $\left(\mathrm{SO}_{3}\right)$ has showed decrease in winter months, it has showed increase in months when water temperature rises and the mount of dissolved oxygen decreases. The highest sulfite $\left(\mathrm{SO}_{3}\right)$ value has been observed in $5^{\text {th }}$ station in September 2013 as $4.20 \mathrm{mg} / \mathrm{L}$, while the lowest value has been observed in $1^{\text {st }}$ station in February 2012 as $0.36 \mathrm{mg} / \mathrm{L}$. Even the highest amount of sulfite (SO3) observed in stream is less than the half of the acceptable upper limit for aquatic life.

It has been seen that the level of sulfate $\left(\mathrm{SO}_{4}\right)$ in all 6 stations on Çınarlı Stream during 2 years is less than the level desired for aquaculture. The level of sulfate $\left(\mathrm{SO}_{4}\right)$ in stream has showed decrease in winter months in all sampling stations. During the study, the amount of sulfate has showed regular increase in all stations between February and September. The highest sulfate $\left(\mathrm{SO}_{4}\right)$ amount in stream has been observed in $5^{\text {th }}$ station in September 2013 as $68.90 \mathrm{mg} / \mathrm{L}$, while the lowest value has been observed in 1s station in February 2012 as 12.12 $\mathrm{mg} / \mathrm{L}$ and the mean value for 2 years of study was 31.76 $\mathrm{mg} / \mathrm{L}$. Under the light of those results, it has been found that even the highest amount of sulfate $\left(\mathrm{SO}_{4}\right)$ in Çınarl stream equals to $1 / 4$ of acceptable limit for aquaculture.

The increases and decreases of sodium ( $\mathrm{Na}$ ) and potassium (K) levels in Çınarlı stream have showed analogy. During the research period, the values of sodium $(\mathrm{Na})$ and potassium $(\mathrm{K})$ in stream have showed increase in spring months when the flow rate and speed of water are high, while they have showed decrease in months when flow rate decreases. The lowest sodium and potassium levels have been observed in $1^{\text {st }}$ station in September 2013 as $33.90 \mathrm{mg} / \mathrm{L}$ and $2.94 \mathrm{mg} / \mathrm{L}$, respectively, while the highest levels have been observed in $6^{\text {th }}$ station in May 2012 as $60.06 \mathrm{mg} / \mathrm{L}$ and $4.42 \mathrm{mg} / \mathrm{L}$. Also as a result of monthly measurements between October 2011 and September 2013, the mean sodium and potassium levels of Çinarlı stream have been found to be $43.69 \mathrm{mg} / \mathrm{L}$ and $3.10 \mathrm{mg} / \mathrm{L}$. 
During the monthly evaluations in Çınarlı stream, the levels of heavy metals of lead, copper, cadmium and ferrous have been found to be very low, even they couldn't be detected in some months. The Çinarlı stream has been found to be $1^{\text {st }}$ class in accordance with Water Pollution Control regulation (WPCR) in terms of heavy metal content, and its heavy metal content was much less than acceptable upper limits.

\section{Results and Discussion}

The mean seasonal values and standard deviation values of water quality parameters which were measured between 09:00 and 10:30 in 4 days of months in determined stations between October 2011 and September 2013 in Çınarlı stream in Hafik district of Sivas city are given in Table 1.

The water quality assessment is frequently used in determining the aquatic pollution and the concentration of polluters in water, sediment and organisms (Mansour and Sidky, 2002). The assessment of water quality in accordance with physico-chemical parameters gives information about the actual situation of that water (Dirican, 2008).

Temperature is an important parameter from the aspect of aquatic life as it alters the viscosity and density of water and affects the speed of biochemical reactions and solubility of gases. It is known that the metabolisms of organisms living in water change with temperature, in particular the fishes (Taş et al., 2010).

Inappropriate water temperature conditions downgrades the development of fishes; the larval cannot reach at nutrition or it leads them to hatch before or after the right time (Aydin, 1995).

During our study, the changes in temperature of Çınarlı stream stayed within the normal limits of seasons. Its temperature declined in winter months, and then increased in summer months in parallel with increasing air temperature. During the monthly water temperature assessments in 6 stations on Çinarlı stream, the seasonal and inter-station changes didn't reach at limit affecting the aquatic life, and the quality of stream was found to be $1^{\text {st }}$ class in accordance with WPCR.

The $\mathrm{pH}$ showing the balance between acid and bases in water is a basic parameter which should be assessed in any study about water chemistry and pollution. As well as it plays role in some chemical reactions in living organisms, it has also a characteristic that increases the toxic effect of some chemical and metals when acidic waters merges with that chemicals and metals (Bektaş et al., 2011). In order for an aquatic media's $\mathrm{pH}$ to not harm the aquatic life, and for that water resource to be able to be used for aquaculture, that $\mathrm{pH}$ level shouldn't excess the limit value of 6.5-8.5 (Kara and Çömlekçioğlu., 2004).

During our study for 2 years in 6 stations on Çınarlı stream, it was determined that the $\mathrm{pH}$ changes of stream weren't excessive and the mean $\mathrm{pH}$ value was 8.28 , which indicates that the water is mildly basic. The $\mathrm{pH}$ value of Çınarlı stream indicates an environment being suitable for aquatic organisms and fishes, and it is $1^{\text {st }}$ class for Control regulation (WPCR) standards.

Dissolved Oxygen (DO) concentration is an important factor for improving the balanced aquatic fauna. As well as it is a very important component for aquatic life, dissolved oxygen is also important for biochemical oxidations (Atay and Pulatsü, 2000). The dissolved oxygen constitutes the very important part of ecological stability and activity of water. Decreases are seen in oxygen concentration with rising air temperature in summers, while increases are seen in winter months when air temperature decreases (Kocataş, 1986).

The dissolved oxygen amount in Çınarlı stream was found to be high in winter months and low in summer months. In fresh waters, the minimum dissolved oxygen amount required for aquatic life is $5 \mathrm{mg} / \mathrm{L}$ (Atay and Pulatsü, 2000). The lowest dissolved oxygen amount in stream was found to be $8.66 \mathrm{mg} / \mathrm{L}$ in $5^{\text {th }}$ station in September 2013, and it is far away from dangerous limit for aquatic life. It was determined that the Çınarlı stream is $1^{\text {st }}$ class in terms of Water Pollution and Control regulation.

Salinite is the concentration of mineral matters dissolved in water, and the expression of dissolved solid matters in each $\mathrm{kg}$ stated in gram (Yanık et al., 2001). The level of salinite constituting an important abiotic factor of waters is as important as physical characteristics of waters, and plays the leading role in inorganic aggregation and the distribution of organisms in aquatic media (Geldiay and Kocataş, 1998). The level of saltiness increases with vaporization and mixing with polluted waters, while it decreases with rains, melting of ices and the mixing fresh waters (Göksu, 2003). The saltiness value is closely related with temperature and electrical conductivity (Mutlu et al., 2013b).

The saltiness rates in study stations on Çınarlı stream showed variance seasonally; the saltiness level have declined in all stations in winter months, while it significantly increased in summer months when vaporization increases, expect $1^{\text {st }}$ station. In general, it was seen that the saltiness situation of stream was appropriate.

Electrical conductivity (EC) is the value of $1 \mathrm{ohm}$ electrical resistance in the column with $1 \mathrm{~cm}$ length and 1 $\mathrm{cm}$ cross-sectional area at $25^{\circ} \mathrm{C}$ temperature. Electrical conductivity may change depending on water temperature, dissolved matters in water (such as salt), and solution content (Özpınar, 2007). Electrical conductivity value is very important in water quality studies; electrical conductivity value excesses $(1000 \mu \mathrm{sx} 10 \mathrm{~cm})^{-1}$ as pollution increases (Polat, 1997). The electrical conductivity capacity of water increases as saltiness increases. That's why; electrical conductivity (EC) is an indicator in saltiness level (Mutlu et al., 2013b).

The electrical conductivity (EC) showed analogy with temperature and saltiness in Çinarlı stream; it was low in all stations during winter, while it significantly increased in all stations during winter, except $1^{\text {st }}$ station. The mean electrical conductivity in Çınarlı stream was found to be $201.34 \mu \mathrm{s} / \mathrm{cm}$, and it indicates that it is in very good conditions in accordance with WPCR.

Suspended solid matters (SSM) are materials in water that have 1 micron or larger sizes but smaller than sand. The suspended solid matters may occur in waters due to erosion, pollution, phytoplankton boom and the transfer of rocks by being eroded (Mutlu, 2013). The aggregation 
of suspended solid matters leads the amount of dissolved oxygen to decrease and eutrophication to occur (Havser, 1996). The suspended solid matter (SSM) content of Çınarlı stream decreased in winter months, and increased in summer months when dissolved oxygen amount decreased and temperature increased. The highest SSM value in stream was observed in $6^{\text {th }}$ station in September 2013 as $6.54 \mathrm{mg} / \mathrm{L}$, while the average value during 2 years of study was $1.83 \mathrm{mg} / \mathrm{L}$. The amount of SSM in stream doesn't present a danger for aquaculture; it is much lower than critical limit. According to WPCR standards, it was determined that the water of Çınarl stream is $3^{\text {rd }}$ class.

Chemical oxygen demand (COD) indicates the amount of oxygen required for oxidation of all matters in water (Atay and Pulatsü, 2000). COD is an important parameter used in determination of pollution in water and waste waters. The chemical oxygen need in waters more than $25 \mathrm{mg} / \mathrm{L}$ indicates the pollution, while the existence more than $50 \mathrm{mg} / \mathrm{L}$ indicates the excessive pollution and toxic danger for aquatic organisms in that water (Güler, 1997).

During the research duration, the chemical oxygen need in Çinarlı stream was found to be very low. The highest value was observed in $5^{\text {th }}$ station in September 2013 as $9.60 \mathrm{mg} / \mathrm{L}$. Even this level is less than half of accepted water pollution limit according to (Güler, 1997). The reason of COD increase in all stations (except $1^{\text {st }}$ station) on stream from March until September is the possible fertilizer, animal wastes and domestic wastes mixing during passage through agriculture fields or villages which may lead to organic pollution. According to WPCR standards, the water of Çinarlı stream was determined to be $1^{\text {st }}$ class.

Table 1 Mean values and standard deviation for some of water quality parameters in Çınarlı Stream

\begin{tabular}{|c|c|c|c|c|c|}
\hline Parameters/seasons & Winter & Spring & Summer & Autumn & $\mathrm{Sd}$ \\
\hline Total alkalinity $\left(\mathrm{mg} / \mathrm{L} \mathrm{CaCO}{ }_{3}\right)$ & 146.56 & 177.19 & 180.79 & 184.96 & 17.50 \\
\hline Total hardness $\left(\mathrm{mg} / \mathrm{L} \mathrm{CaCO}_{3}\right)$ & 145.79 & 176.23 & 179.81 & 183.95 & 17.39 \\
\hline Nitrite $\left(\mathrm{NO}_{2}\right)(\mathrm{mg} / \mathrm{L})$ & 0.0002 & 0.0011 & 0.0024 & 0.0010 & 0.00 \\
\hline Nitrate $\left(\mathrm{NO}_{3}\right)(\mathrm{mg} / \mathrm{L})$ & 0.04 & 0.14 & 0.57 & 0.44 & 0.25 \\
\hline Ammonium nitrogen $(\mathrm{mg} / \mathrm{L})$ & 0.0013 & 0.0083 & 0.0340 & 0.0103 & 0.01 \\
\hline Chloride (mg/L) & 11.47 & 12.57 & 12.10 & 10.63 & 0.84 \\
\hline Calcium (mg/L) & 8.69 & 14.59 & 14.46 & 13.24 & 2.77 \\
\hline Magnesium (mg/L) & 8.38 & 14.01 & 14.11 & 12.99 & 2.71 \\
\hline Sulfite (mg/L) & 0.64 & 1.24 & 2.64 & 2.39 & 0.95 \\
\hline Sulfate $\left(\mathrm{SO}_{4}^{-2}\right)(\mathrm{mg} / \mathrm{L})$ & 17.81 & 20.67 & 43.46 & 45.11 & 14.52 \\
\hline Sodium $(\mathrm{Na})(\mathrm{mg} / \mathrm{L})$ & 36.36 & 54.20 & 46.24 & 37.98 & 8.23 \\
\hline Potassium $(\mathrm{K})(\mathrm{mg} / \mathrm{L})$ & 2.03 & 3.77 & 3.51 & 3.10 & 0.77 \\
\hline Lead $(\mu \mathrm{g} / \mathrm{L})$ & 1 & 4 & 8 & 6 & 0.00 \\
\hline Copper $(\mu \mathrm{g} / \mathrm{L})$ & 5 & 18 & 13 & 9 & 0.00 \\
\hline Cadmium $(\mu \mathrm{g} / \mathrm{L})$ & 0.7 & 1.1 & 1.4 & 1.8 & 0.00 \\
\hline Iron $(\mathrm{mg} / \mathrm{L})$ & 0.0007 & 0.0060 & 0.0040 & 0.0020 & 0.00 \\
\hline
\end{tabular}

Biological oxygen demand (BOD) is the amount of oxygen which bacteria need for decompose the organic matters in oxygenic conditions (Atay and Pulatsü, 2000). From the aspect of water qualification, biological oxygen demand (BOD) is an indicator of pollution (Egemen and Sunlu, 1999). The highest BOD value in clean waters should be $2 \mathrm{mg} / \mathrm{L}$, and it may be $10 \mathrm{mg} / \mathrm{L}$ and higher (Çiçek and Ertan, 2012).

The highest BOD value in Çınarlı stream was observed in $5^{\text {th }}$ station in September 2013 as $6.00 \mathrm{mg} / \mathrm{L}$ which is not a problem from the aspect of aquaculture (Çiçek and Ertan, 2012). Also it was determined that the water is $2^{\text {nd }}$ quality according to WPCR.

The total alkalinity and total hardness values of Çinarlı stream have showed close and similar values in all stations during the sampling and research period. In waters in calcareous soils, the total hardness and total alkalinity values are frequently close or equal to each other (Boyd and Tucker, 1998).

Samsunlu (1999), has stated that hardness in waters occurs mainly due to calcium and magnesium salts as a result of interaction with soil and rocks, and it constitutes combination with other ions of mineral acids of carbonate, bicarbonate, sulfate, and chloride.

Total hardness is one of the most important parameters for fresh water analyses. Hard waters are not suitable for aquaculture, because hard waters increase the toxic effects of toxic materials in environment (Göksu, 2003).

The highest total hardness value in Çınarlı stream was observed in $6^{\text {th }}$ station in June 2012 as $206.36 \mathrm{mg} / \mathrm{L}$ $\mathrm{CaCO}_{3}$, while the mean value during 2 years of study in 6 stations was found to be $171.4 \mathrm{mg} / \mathrm{L} \mathrm{CaCO}_{3}$. It was observed that the stream belongs to the group of mildly hard waters according to WPCR, and it doesn't present a danger in terms of aquaculture (Göksu, 2003).

The total alkalinity of water is an index of total concentration of titrable bases. According to WPCR and table water standards (Anonymous, 2010), the waters involving total alkalinity of $20-300 \mathrm{mg} / \mathrm{L} \mathrm{CaCO}_{3}$ are accepted as normal waters.

During the research period, the total alkalinity and total hardness values of Çınarlı stream have showed parallelism in all stations, and according to Boyd and Tucker, 1998, total alkalinity value have been 1-2 mg/L more than total hardness values. The total alkalinity values of stream comply with water quality criteria, and it has been determined that it is within optimum limits for aquatic organisms and aquaculture. Also it was found that the water is in very good conditions according to WPCR. 
The most widespread nitrogen compounds in natural waters are nitrite, nitrate and ammonium nitrogen. The water quality can be determined by measuring those compounds. The resource of those nitrous matters might be the compounds transferred by domestic and industrial wastes while cleaning, as well as it can be atmospheric nitrogen transferred by rain, and nitrate salt in structure of soil (Taş et al., 2010). The high levels of nitrous compounds of nitrite $\left(\mathrm{NO}_{2}\right)$, nitrate $\left(\mathrm{NO}_{3}\right)$ and ammonium nitrogen $\left(\mathrm{NH}_{4}\right)$ may show toxic effect for aquatic organisms. In such a case, the toxicity of nitrous compounds increases as $\mathrm{pH}$ and water temperature increase (Mutlu et al., 2013a). Nitrate $\left(\mathrm{NO}_{3}\right)$ toxicity is less than that of nitrite and ammonium nitrogen (Tepe et al., 2006).

It has been determined in performed measurements that the nitrite $\left(\mathrm{NO}_{2}\right)$, nitrate $\left(\mathrm{NO}_{3}\right)$ and ammonium nitrogen levels of Çınarlı stream are less in winter periods than other months. The highest nitrite $\left(\mathrm{NO}_{2}\right)$ in stream was observed in $5^{\text {th }}$ station in July 2012 as $0.0030 \mathrm{mg} / \mathrm{L}$, and even this value is much less than the limit being dangerous for aquaculture. Also the quality of water is $2^{\text {nd }}$ quality according to WPCR in terms of nitrite $\left(\mathrm{NO}_{2}\right)$.

It was determined that the nitrate $\left(\mathrm{NO}_{3}\right)$ level of stream is very low. While the amount of nitrate decreased in all stations during winter, in September when the dissolved oxygen amount is at lowest level and the water temperature is at the highest level, the highest level in $5^{\text {th }}$ station as $0.90 \mathrm{mg} / \mathrm{L}$ is $1 / 5$ of acceptable level. According to WPCR standards, the water of Çınarlı stream is $1^{\text {st }}$ quality in terms of nitrate $\left(\mathrm{NO}_{3}\right)$.

The ammonium nitrogen $\left(\mathrm{NH}_{4}\right)$ levels in Çınarlı stream showed similarities with levels of nitrite $\left(\mathrm{NO}_{2}\right)$ in all stations during the study. The highest value of 0.060 $\mathrm{mg} / \mathrm{L}$ found in $5^{\text {th }}$ station in July 2013 is obviously appropriate for aquaculture. According to WPCR standards, the stream is $2^{\text {nd }}$ quality in terms of ammonium nitrogen $\left(\mathrm{NH}_{4}\right)$ content.

The chloride anion which exists in all natural waters is an important component of natural waters, and affects the distribution of organisms. As well as chloride in waters may originate from domestic, agricultural and industrial wastes, it can be mineral-originated (Çiçek and Ertan, 2012). Chloride ion may exist in natural waters in rate of 0-30 mg/L (Taş et al., 2010). The highest concentrations of chloride are seen in rainy seasons (Şen and Gölbaşı, 2008).

In harmony with Şen and Gölbaşı's study, the highest chloride value of Çınarlı stream was observed in May (the rainiest month) in $1^{\text {st }}$ station as $13.24 \mathrm{mg} / \mathrm{L}$ while the lowest value was observed in September 2013, when the vaporization and air temperature are at highest levels, in $5^{\text {th }}$ station as $9.84 \mathrm{mg} / \mathrm{L}$. The mean chloride value of stream is $11.69 \mathrm{mg} / \mathrm{L}$, and according to Taş 2011, it doesn't present any danger for aquaculture and aquatic life. Also the stream was found to be $1^{\text {st }}$ class water in terms of chloride content according to WPCR standards.

The calcium and magnesium are among the most important dissolved solid matters in water. During the study, the increases and decreased in magnesium and calcium levels in Çınarlı stream have showed parallelism. They reached at their peak values in months when water flow rate and speed reached at highest levels.

The calcium, which is very important for all of organisms, is one of the most widespread elements existing in natural waters. In normal waters, the concentration of calcium (Ca) between 5 and $60 \mathrm{mg} / \mathrm{L}$ is accepted as normal. In mildly hard waters, the concentration between 80 and $100 \mathrm{mg} / \mathrm{L}$ is accepted as normal, as well as the highest acceptable value or calcium is $75 \mathrm{mg} / \mathrm{L}$ (Taş et al., 2010). The highest calcium level of Çınarlı stream has been observed in $6^{\text {th }}$ station in June 2012 as $16.08 \mathrm{mg} / \mathrm{L}$, while the average of monthly measurements during 2 years of study is $12.74 \mathrm{mg} / \mathrm{L}$ for 6 stations. According to Taş (2011), the water of Çınarlı stream is suitable for aquaculture and aquatic life.

Magnesium is one of the most widespread elements in eschar; it doesn't exist as natural element because it is excessively active. As well as it takes place in compound of many rocks and minerals, it exists in lime stones and consequently in dolomite stones at most in $\mathrm{MgCO}_{3}$ form (Güler, 1997). Magnesium (Mg) has vital importance for chlorophyllous plants in water, and controls the phosphor metabolism in algae, fungi, and bacteria. That's why; the existence of appropriate amount of magnesium in fresh water is important (Çiçek and Ertan, 2012). In normal waters, the value of magnesium is higher than $5 \mathrm{mg} / \mathrm{L}$ and less than $60 \mathrm{mg} / \mathrm{L}$, while $60-100 \mathrm{mg} / \mathrm{L}$ is accepted as mildly hard waters (Mutlu et al., 2013b).

The highest magnesium level in Çınarlı stream was detected in $6^{\text {th }}$ station in June 2012 as $15.60 \mathrm{mg} / \mathrm{L}$, while the average of monthly measurements during 2 year of study was $12.37 \mathrm{mg} / \mathrm{L}$. The magnesium concentration of stream is within the limits recommended by Mutlu et al. (2013).

The phosphor being a key product exists in waters in phosphate form. The phosphate exists in natural waters in concentration between 0.01 and $0.03 \mathrm{mg} / \mathrm{L}$, and it affects the productivity of aquatic organisms, such as planktons, and the water resources (Tepe and Boyd, 2003). The nonexistence of enough amount of phosphor in waters is the most important factor limiting the development of aquatic creatures (Atay and Pulatsü, 2000). The phosphor reaches at rivers, lakes and seas from various resources such as commercial fertilizers, other agricultural inputs, sewages, detergents, and wastes of food industry.

In Çınarlı stream, the highest amount of phosphate which is an important nutritive mineral affecting the productivity was observed in $5^{\text {th }}$ station in October 2011 as $0.294 \mathrm{mg} / \mathrm{L}$, while the average of monthly measurements during the study is $0.135 \mathrm{mg} / \mathrm{L}$. According to Tepe and Boyd (2003), the amount of phosphor in Çınarlı stream is suitable for aquaculture. The reason of increase of the amount of phosphor in Çınarlı stream in September- October period is thought to arise from the second fertilization which is required for wheat plant which is widely planted, and the phosphate content of that fertilizer. The phosphate content of fertilizers mixes into stream through rain and surface waters. Also the Çınarlı stream is accepted as $3^{\text {rd }}$ quality water in terms of phosphate $\left(\mathrm{PO}_{4}\right)$ content according to WPCR standards.

The sulfite $\left(\mathrm{SO}_{3}\right)$ constituting the essential part of vital materials exist widely in eschar, but the existence of sulfite in water more than $10 \mathrm{mg} / \mathrm{L}$ is dangerous 
(Mutlu.et.al.2013a). The measured sulfite in study is $\mathrm{NaSO}_{3}$ (sodium sulfite). The highest sulfite value in study was observed in $5^{\text {th }}$ station in September 2013 as 4.20 $\mathrm{mg} / \mathrm{L}$. Even the highest sulfite amount determined in stream is less than half of acceptable limits proposed by Mutlu.et.al. 2013a. and it doesn't present any danger from the aspect of aquaculture.

The sulfate $\left(\mathrm{SO}_{4}\right)$ among natural anions of waters should exist in natural waters in order for biological productivity to increase (Taş et al., 2010). Sulfate is effective in development of plants, biological productivity, and protein metabolism in natural waters. The sulfate deficiency prevents algae development and suppresses the plat development. It is reported that various industrial wastes, agricultural activities, domestic wastes and the effects of sea waters increase the concentration of sulfate $\left(\mathrm{SO}_{4}\right)$ in fresh water (Çiçek and Ertan, 2012). The level of sulfate in natural waters varies between 5 and $100 \mathrm{mg} / \mathrm{L}$, but the maximum sulfate level required for aquatic products was determined as $90 \mathrm{mg} / \mathrm{L}$ (Küçük, 2007).

The highest level of sulfate in Çinarlı stream was observed in $5^{\text {th }}$ station in September 2013 as $68.90 \mathrm{mg} / \mathrm{L}$, while the study average was found to be $31.76 \mathrm{mg} / \mathrm{L}$. Under the lights of those results, it is seen that even the highest sulfate concentration in stream is not higher than upper limit for aquatic organisms as stated by Küçük (2007), and that there is no danger from the aspect of water products. The stream is accepted as $1^{\text {st }}$ quality from the aspect of sulfate content according to WPCR standards.

The changes of sodium $(\mathrm{Na})$ and potassium $(\mathrm{K})$ in all of the study stations on Çinarlı stream during the study showed parallelism. Sodium (Na) exists in aquatic environment in $\mathrm{Na}_{2} \mathrm{SO}_{4}$ and $\mathrm{Na}_{2} \mathrm{SO}_{3}$ form, and its concentration in natural waters varies between 2 and 100 $\mathrm{mg} / \mathrm{L}$ (Boyd, 1998). Potassium (K) exists in aquatic media in $\mathrm{K}^{+}$and $\mathrm{K}_{2} \mathrm{SO}_{4}$ form, and is a nutrient element playing role in plant organisms' development. The concentration between 1 and $10 \mathrm{mg} / \mathrm{L}$ in waters with normal hardness, and between 10 and $15 \mathrm{mg} / \mathrm{L}$ is accepted as normal (Taş, 2006).

The sodium and potassium values of Çınarlı stream were observed to increase in months when flow rate increases and decrease in months when flow rate decreases. The highest sodium value was observed in $6^{\text {th }}$ station in May 2012 as $60.06 \mathrm{mg} / \mathrm{L}$ which is accepted as normal according to Boyd (1998). The highest potassium level was observed in $6^{\text {th }}$ station in May 2012 as 4.42 $\mathrm{mg} / \mathrm{L}$ which is within the acceptable limits stated by Taş (2006). It was stated that the stream is suitable for aquaculture in terms of sodium $(\mathrm{Na})$ and potassium $(\mathrm{K})$ values, and that the stream is $1^{\text {st }}$ quality in accordance with WPCR standards.

The values of lead, copper, cadmium and ferrous elements among the heavy metal elements were found to be very high in all 6 stations during monthly evaluations; even none of them could be detected in February in some stations. In September 2013 when the water temperature was highest and the dissolved oxygen amount was the lowest, the highest lead $(\mathrm{Pb})$ value was observed in $5^{\text {th }}$ station as $9 \mu \mathrm{g} / \mathrm{L}$, which is not dangerous for aquaculture.
Also from the aspect of copper, cadmium, lead and ferrous elements, the water of Çınarlı stream is $1^{\text {st }}$ quality in accordance with WPCR standards.

During the study which has been conducted about the monthly and seasonal changes of Çınarlı stream's water quality characteristics between October 2011 and September 2013 in 6 stations, the water samples obtained from stations were evaluated from the aspect of physical and chemical water quality, and assessed from the aspect of water quality and aquaculture. As a result of this study, it was seen that there is not any important problem from the aspect of water pollution. But because the agriculture is widely common in near agricultural fields, the leakage of water from fields through surface waters to Çınarlı stream, and the interaction with waters from animal breeding facilities near Çınarlı stream should be prevented, and the immediate measures must be taken about the organic and domestic wastes of Çınarlı, Bahçecik and Koşutdere villages where the stream passes through.

According to the results of our study; the Çınarlı stream is under the pressure of pollution, the regulations about the protection of rivers should be carefully implemented, and the ecological disruption should be prevented. The actual situation of stream is $3^{\text {rd }}$ quality as stated in WPCR that the lowest parameter value determines the quality of water when compared with table and daily usage water standards. In order to protect Çınarlı stream from pollution, to improve the water quality, to protect the natural fish stocks, to sustain the natural ecological balance of other aquatic organisms, and because of its importance from the aspect of irrigation of near agricultural fields, the stream should be periodically monitored. It is also a necessity because it provides the water requirement of Çınarlı, Bahçecik and Koşutdere villages.

\section{References}

Anonymous. 2010. Water Pollution Control Regulation (WPCR), the Republic of Turkey Official Gazette No. 25687, Ankara, Turkey

Atay D, Pulatsü S. 2000. Water Pollution and Control. Ankara University Faculty Publication No: 1513, Ankara.

Aydin F. 1995. Water in Fish Production Criteria Lecture Notes (Unpublished). Ankara University, Faculty of Agriculture Publications.

Bektaş S, Yıldırım A, Becer Özvarol ZA. 2011. Compression of Some Water Quality Parameters of the Different Trout Streams in Çoruh Basin. Biological Sciences Research Journal. 4:1.61-66 p.

Boyacıŏlu H, Boyacıoglu H. 2003. Water Quality Assessment by Statistical Methods. SKKD. Volume: 14.3. 9-17 p.

Boyd CE. 1998. Water Quality for Pond Aquaculture. Alabama Aquacultural Experiment, USA.

Boyd CE, Tucker CS. 1998. Pond Aquaculture Water Quality Managent. Kluwer Academic Publishers, 700 p. USA.

Boyd CE, Tucker CS. 1992. Water Quality Pond Soil Analysis for Aquaculture Alabama Agricultural Experiment Station, Auburn University, Alabama, USA.

Cicek NL, Ertan OO. 2012. Determination of the Water Quality of Köprüçay River (Antalya) According to the PhysicoChemical Parameteres Ecology 21 (84): 54-65p.

Dirican S. 2008. Evaluation of water quality of Kilıçkaya Dam Lake (Sivas-Turkey), J.Agric.Fac.HR.U.,12(4): 25-31 p. 
Geldiay R, Kocataş A. 1998. Check in Marine Ecology. Ege University, Faculty of Science Publications. No: 31 Izmir.

Geyikçi F, Büyükgüngör H. 2010 Surface Water in The Black Sea Region of Physical Parameters in the Evaluation of Calcein. Turkey's Coastal and Marine Areas VIII. National Congress. Proceedings, April 27-May 1, Trabzon. 1429$1436 \mathrm{p}$.

Göksu MZL. 2003. Water Pollution Textbook. Cukurova University, Faculty Of Aquaculture Feeds. No: 17. Adana.

Guler Ç. 1997. Water Quality and Environmental Health of the Source Array. 43:95 p. Ankara.

Havser B. 1996. Practical Mannual of Wastewater Chemistry. Lewis Publishers, $137 \mathrm{p}$.

Kara C, Çömlekçioğlu U. 2004 Investigation of Karacay's (Kahramanmaraş) Pollution with Biological and PsychoChemical Parameters. KSU Journal of S 1 cience and Engineering 7(1). 1-7 p.

Küçük S. 2007. Büyük Menderes River Water Quality Measurement in terms of the Fisheries Investigation. Adnan Menderes University. Journal of the Faculty of Agriculture, 4 (1-2) : 7-13 p.

Mansour SA, Sidky MM. 2002. Exotoxicological Studies.6. The First Comparative Study Between Lake Quaran And Wadi El-Rayan Wetland (Egypt), with Respect Contamination of Their Major Components. Food Chemistry. 82: 181-189 p.

Mutlu E. 2013. Studies on Seasonal (Monthly) Changes in Biochemical Parameters of chub (Leuciscus cephalus) Living in Kizılırmak Basin of Sivas. Ataurk University Institute of Science in Fisheries Engineering U.S. Doctoral Thesis, Erzurum

Mutlu E, Demir T, Yanık T. 2013a. Cermik Stream (HafikSivas) and Monthly Changes in Water Quality Characteristics. Central Anatolia Region Proceedings of the First Congress of Agriculture and Food. Volume III. 57-67 p.
Mutlu E, Demir T, Kutlu B, Yanık T. 2013b. Determination of Water Quality Parameters in Sivas - Kurugöl Lake. Turkish Journal of Agriculture- Food Science and Technology, 1(1): 37-43 p.

Okur B, Yener H, Okur N, İrget E. 2001. Monthly And Seasonal Variation Of Some Pollution Parameters Of Büyük Menderes River. Pamukkale University Engineering College. Journal of Engineering Sciences.7:2. 243-250 p.

Özpınar Z. 2007. Göksu Be Determined By A Photometric Method Of Water Quality In The Delta. Mersin University, Institute Of Science In Environmental Engineering USA. Master's Thesis, Mersin.

Polat M. 1997. Streams and Lakes Monitored Physical and Chemical Parameters. Water Quality Management Seminar. DSI General Directorate. 45-47, Ankara.

Samsunlu A. 1999. Environment Engineering Chemistry. SamEnvironment Technologies Press, İstanbul

Sen B, Gölbasi S. 2008. A Study on Some Physical and Chemical Properties of Kürk Stream Discharging into Lake Hazar, Vol 25 (4) :353-358 p İzmir

Tas B. 2006. Investigation of Water Quality of Derbent Dam Lake (Samsun). Ecology 15-61, 6-15 p.

Tas B. 2011. Gaga Lake (Ordu-Turkey) Examination of Water Quality. Karadeniz Technical University, Science Magazine. Year: 2 Volume: 2 Issue: 3 43-61 p. Trabzon.

Taş B, Candan AY, Can ÖV, Toprak AŞ. 2010. Some physicochemical features of lake Ulugöl (Ordu-Turkey). Journal of Fisheries Sciences. 4: 3. 254-263 p.

Tepe Y, Boyd CE. 2003. A Reassesment of Nitrogen Fertilization for Sunfish Ponds. Journal of World Aquaculture Society. 34: 4, 505-511 p.

Tepe Y, Ates A, Mutlu E, Tore Y. 2006. Water quality of Hasan stream (Erzin-Hatay) and its montly variations. E.U. Journal of Fisheries \& Aquatic Sciences, Volume : 23, Suppl. (1/1): $149-154 \mathrm{p}$.

Yanık T, Ciltaş A, Aras M. 2001. Introduction to Water Quality in Aquaculture. Ataturk University Faculty of Agriculture Course Material, No: 225 Erzurum. 